\title{
Adsorption of Procion Red Dye on Natural Bentonite: A Kinetic Studies
}

\author{
Tarmizi Taher ${ }^{1}$, Aldes Lesbani ${ }^{1,2, *}$ \\ ${ }^{1}$ Intergrated Research Laboratory, Graduate Program, Sriwijaya University Jl Padang Selasa, Bukit Besar Palembang 30129, \\ Indonesia. \\ ${ }^{2}$ Department of Chemistry, Faculty of Mathematic and Natural Sciences, Sriwijaya University Jl. Raya Palembang Prabumulih \\ Km32 Ogan Ilir 30662, Indonesia \\ *Corresponding author.email: aldeslesbani@yahoo.com
}

Article history

\begin{tabular}{llll} 
Received & Received in revised form & Accepted & Available online \\
29 February 2016 & 15 March 2016 & 28 March 2016 & 15 April 2016 \\
\hline
\end{tabular}

\begin{abstract}
Adsorption of procion red on natural bentonite was studied by kinetic study to know the reactivity of procion red. Kinetic adsorption was determined using batch adsorption system at various times in several concentrations of procion red. Time of adsorption was investigated at 5, 10, 20, 30, 45, 60, 90, and 120 minutes in 10, 25,50 , and $75 \mathrm{mg} / \mathrm{L}$ of procion red. The data was calculated using Langmuir-Hinshelwood kinetic equation. The diffusions process of procion red into bentonite at lower concentration was faster than at higher concentration in general with fit correlation between $[(\ln (C o / C)) / C]$ vs $t / C$ from Langmuir-Hinshelwood data. The adsorption procion red on bentonite data at various times shows Langmuir monolayer adsorption process in the surface of bentonite.

Keyword: adsorption, procion red, natural bentonite, kinetic
\end{abstract}

\begin{abstract}
Abstrak (Indonesian): Adsorpsi procion merah pada bentonit alam telah dipelajari melalui studi kinetik untuk mengetahui reaktivitas procion merah. Kinetika adsorpsi ditentukan menggunakan sistem adsorpsi simultan pada berbagai waktu dalam beberapa konsentrasi procion merah. Waktu adsorpsi dipelajari pada 5, 10, 20, 30, 45, 60, 90, dan 120 menit pada konsentrasi procion merah 10, 25, 50, dan $75 \mathrm{mg} / \mathrm{L}$. Data dihitung menggunakan persamaan kinetika Langmuir-Hinshelwood. Proses difusi procion merah ke dalam bentonit pada konsentrasi rendah lebih cepat dibanding pada konsentrasi lebih tinggi secara umum dengan hubungan korelasi yang lurus antara $[(\ln (\mathrm{Co} / \mathrm{C})) / \mathrm{C}]$ versus $t / C$ dari data Langmuir-Hinshelwood. Adsorpsi procion merah pada bentonit dengan berbagai variasi waktu adsorpsi menunjukkan proses adsorpsi satu lapisan pada permukaan bentonit.
\end{abstract}

Katakunci: adsorpsi, procion merah, bentonit alam, kinetik

\section{Introduction}

Recently, Indonesia's textile industry has been raised as a direct result of the increasing of the fashion need in Indonesia. That phenomenon is increasing Indonesia economic development. On the other hand, environmental risk is to be a serious problem. The textile factories produce colored dye wastewater disposal that harmful for aquatic organism even for human body. Moreover, many dyes used in textile factories are consisted by reactive group, such as aromatic and amines with high carcinogenic properties [1].

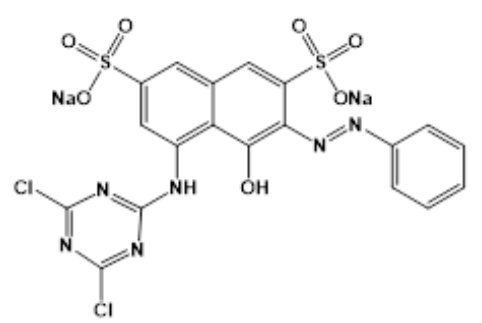

Figure 1. Chemical structure of procion red dye
Procion red dye as illustrated in figure 1 is one of reactive dye that widely used in textile industry due to its reactivity and color stability [2]. This dye is also nonbiodegradable under aerobic condition.

The removal of synthetic dye in waste industrial water has been studied in various ways. Many conventional technique including biological treatment, chemical and physical treatment are not effective enough to completely remove the synthetic dyes in textile industry wastewater disposal [3]. Recently, the adsorption technique is widely used as economical and environmentally friendly technique to remove dye contaminant in textile industry wastewater [4]. Although currently activated carbon is the most widely used adsorbent for dyes removal, the used of activated carbon is limited by its high cost production and regeneration problem [5].

The development of low-cost adsorbent materials for adsorption process has been tested such as natural zeolites, bentonites, or silica sands and shows high activity for adsorption of dyes in liquid system [6]. 
Natural bentonite is inexpensive material and largely available layer materials that have been widely used as a adsorbent material for many waste water pollutant due to its chemical and physical stability, high surface area, and high cation exchange capacity [7]. Natural bentonite is also available in large quantities and easily obtained in tropical country such as Indonesia [8]. Natural bentonite was largely used as effective adsorbent for several dyes such as congo red [9], methylene blue [10], procion red [2], basic red [11], reactive yellow [1], and also other acidic and basic dyes [12]. These process were emphasized on adsorption process only and limited study was found for kinetic studies in term of reactivity of adsorbate into adsorbent.

In the present work, adsorption of procion red dyes using natural bentonite was studied through kinetic studies. Adsorption rate constant from various concentration of procion red dye in several adsorption times was calculated using Langmuir-Hinshelwood equation. This equation assumed adsorption of procion red on bentonite was occurred in single layer on bentonite. Thus the adsorption rate constant was determined by plotting $[\ln (\mathrm{Co} / \mathrm{C}) / C]$ versus $t / C$ form this equation.

\section{Experimental Sections}

\subsection{Chemicals and Instrumentations}

Chemical used in this research (procion red dye) is supplied from Sigma Aldrich. Bentonite clay sample is obtained from Sarolangun District of Jambi Province. The bentonite clay characterization was performed using Shimadzu X-Ray Diffractometer Lab-X type 6000 at scanning speed 1 deg. $\mathrm{min}^{-1}$. The concentration of procion red dye solution is determined by spectrophotometry technique using Thermo Scientific Spectrophotometer UV-Visible Genesys ${ }^{\mathrm{TM}} 20$.

\subsection{Natural Bentonite Preparation}

Natural bentonite sample used in this research was grounded from Sarolangun district, Jambi Province, Indonesia. The sample was washed twice with aquades then dried in oven at $80{ }^{\circ} \mathrm{C}$. Bentonite sample then destructed and sieved to pass 100 mesh particle size using ASTM standard sieve. The bentonite sample then characterized using powder XRD.

\subsection{Procion Red Dye Preparation}

Procion red dye stock solution $(1000 \mathrm{mg} / \mathrm{L})$ was prepared by diluting $1 \mathrm{~g}$ of procion red dye powder into $1000 \mathrm{~mL}$ ultra-pure water on volumetric flask. Standard solution of procion red dye was prepared by diluting the dye stock solution into desired concentration.

\subsection{Adsorption Studies}

Batch experiments of procion red dye adsorption onto natural bentonite were conducted by adding $2 \mathrm{~g}$ of natural bentonite clay to $50 \mathrm{~mL}$ procion dye $(10,15,25$,
$50,75 \mathrm{mg} / \mathrm{L}$ ) on a horizontal shaker equipped with 250 $\mathrm{ml}$ Erlenmeyer flask at room temperature. After a period of time, the dye solution was separated from the adsorbent and the procion red dye concentration was determined using UV-Vis spectrophotometer at 530 wavelengths.

The amount of procion red dye adsorbed onto natural bentonite clay calculated using the following equation:

$$
q=\frac{\left(C_{0}-C_{e}\right) V}{m}
$$

where $q$ is the amount of procion red dye adsorbed per unit weight of natural bentonite clay $(\mathrm{mg} / \mathrm{g}), \mathrm{C}_{0}$ is the initial concentration of procion red dye $(\mathrm{mg} / \mathrm{L}), C_{e}$ is the concentration of procion red dye at equilibrium time $(\mathrm{mg} / \mathrm{L}), \mathrm{V}$ is volume of the solution, and $m$ is dosage of the natural bentonite clay used $(\mathrm{g})[13]$.

The kinetics of adsorption process was studied by monitoring the amount of dye adsorbed with time. The adsorption time than varying from 5 to 120 minutes. The data were calculated using following equation:

$$
\ln \frac{\left(C_{0} / C\right)}{C}=k_{1} \frac{t}{C}+K
$$

Where $C_{0}$ is initial concentration of procion red dye, $\mathrm{C}$ is the concentration of procion red dye after $t$ minutes and $\mathrm{K}$ is adsorption equilibrium constant [14].

\section{Result and Discussion}

\subsection{Characterization of natural bentonite}

$\mathrm{XRD}$ powder pattern of natural bentonite is shown in Figure 2 showing typical diffraction peak of bentonite at $2 \theta$ of about $5^{\circ}$ with wide and high pattern. Other diffraction peaks at $2 \theta$ of about $19^{\circ}, 20-23^{\circ}, 26^{\circ}$, and $39^{\circ}$ were related with others minerals. Diffraction peak at $2 \theta$ of about $19^{\circ}$ related with illite which was layer material similar with montmorillonite at $2 \theta$ of about $20-23^{\circ}$ and $26^{\circ}$. Diffraction peak at $2 \theta$ of about $39^{\circ}$ is related with quartz. These minerals were associated in bentonite due to layer materials in natural system. As for adsorbent, natural bentonite was washed with water three times and dried at $100{ }^{\circ} \mathrm{C}$ overnight.

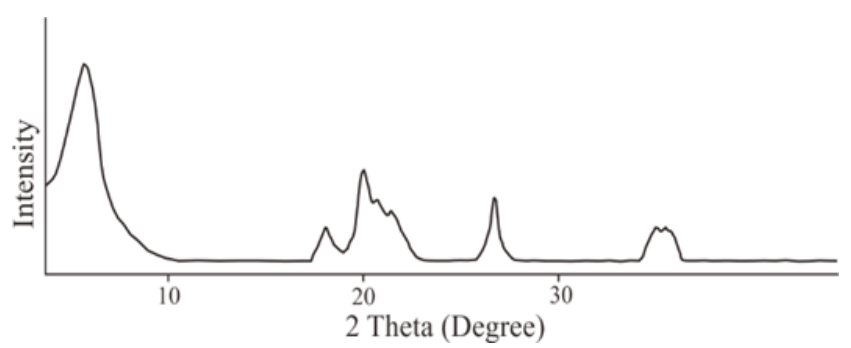

Figure 2. XRD powder pattern of natural bentonite clay

\subsection{Kinetic studies}

Figure 3 shows the effect of adsorption time on the adsorption of procion red onto bentonite. The adsorption 
at initial time was very fast and the adsorption reach equilibrium at about 60 minutes in all concentration of procion red. In this time, all active sites of bentonite were fully filled with procion red as adsorbate. However, from the adsorption profile, adsorption process was slow growth up to equilibrium at 45 minutes. Then adsorption time at 60 minutes was selected as adsorption equilibrium.

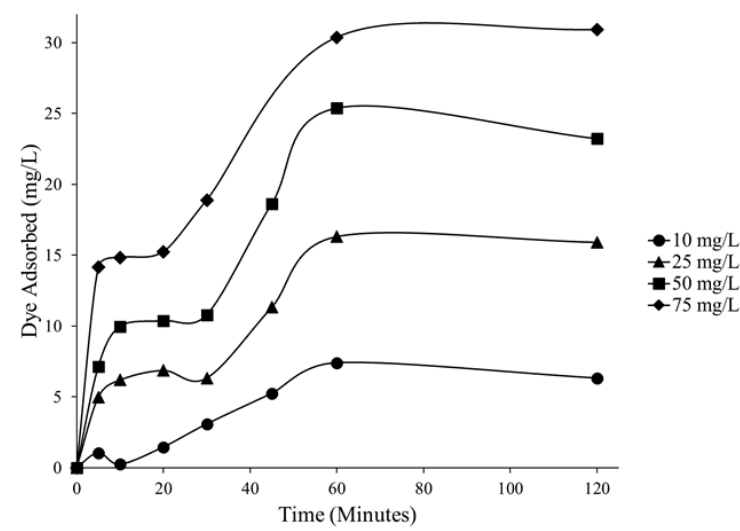

Figure 3. Effect of adsorption time

Kinetic study in the adsorption process is an important value on the study of the removal dyes as pollutant. Langmuir-Hinshelwood adsorption rate equation is used in the assumption that the adsorption obeyed Langmuir isotherm model with first order adsorption reaching equilibrium. The first order adsorption rate constant $\left(k_{1}\right)$ is calculated based on slope of equation (2) by fitting $[\ln (C o / C) / C]$ vs $t / C$. The data in Figure 3 was calculated using Langmuir-Hinshelwood equation and shown in Figure 4. It was found that correlation coefficient was fitted well. The good agreement of the adsorption data indicated the adsorption of procion red on bentonite following first order Langmuir-Hinshelwood equation.
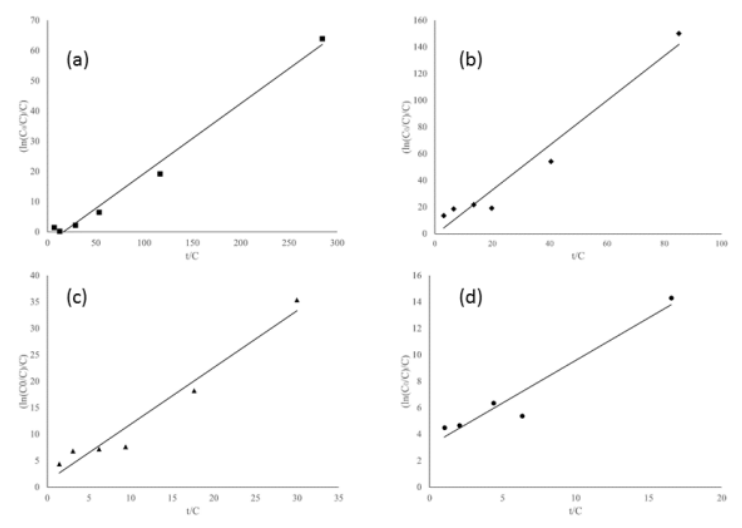

Figure 4. Adsorption kinetics of procion red dye onto natural bentonite clay

Adsorption rate constant $\left(k_{l}\right)$ for each concentration of procion red on bentonite was summarized in Table 1 .
The data in Table 1 is clearly shows that $k_{1}$ almost decrease with increasing concentration of procion red. These phenomena can be easily explained due to saturated procion red can decrease reactivity to be bonded or entrapped onto bentonite. According to $\mathrm{Hu}$ et al. [15] dyes can be adsorbed on bentonite through physical and chemical mechanisms which can be occurred in this process.

Table 1. Kinetic parameters of procion red dye adsorption onto bentonite clay

\begin{tabular}{lll}
\hline $\mathrm{C}_{0}(\mathrm{mg} / \mathrm{L})$ & $k_{l}\left(\mathrm{~min}^{-1}\right)$ & $\mathrm{R}^{2}$ \\
\hline 10 & 0.0231 & 0.9873 \\
25 & 0.0168 & 0.9599 \\
50 & 0.0107 & 0.9576 \\
75 & 0.0064 & 0.9360 \\
\hline
\end{tabular}

\section{Conclusion}

Adsorption rate of procion red on bentonite at lower concentration was faster than higher concentration. Langmuir-Hinshelwood kinetic model was fit well with experiment data showing monolayer adsorption process procion red on bentonite.

\section{References}

[1] Q. Li, Q.-Y. Yue, Y. Su, B.-Y. Gao, and J. Li, "Two-step kinetic study on the adsorption and desorption of reactive dyes at cationic polymer/bentonite," $J$. Hazard. Mater., vol. 165, no. 1, pp. 1170-1178, 2009.

[2] A. Rahman, T. Urabe, and N. Kishimoto, "Color Removal of Reactive Procion Dyes by Clay Adsorbents," Procedia Environ. Sci., vol. 17, pp. 270 278, 2013.

[3] W. Lemlikchi, N. Drouiche, N. Belaicha, N. Oubagha, B. Baaziz, and M. O. Mecherri, "Kinetic study of the adsorption of textile dyes on synthetic hydroxyapatite in aqueous solution," J. Ind. Eng. Chem., vol. 32, pp. 233-237, 2015.

[4] M. Toor and B. Jin, "Adsorption characteristics, isotherm, kinetics, and diffusion of modified natural bentonite for removing diazo dye," Chem. Eng. J., vol. 187, pp. 79-88, 2012.

[5] S. Agarwal, I. Tyagi, V. K. Gupta, A. R. Bagheri, M. Ghaedi, A. Asfaram, S. Hajati, and A. A. Bazrafshan, "Rapid adsorption of ternary dye pollutants onto copper (I) oxide nanoparticle loaded on activated carbon: Experimental optimization via response surface methodology," J. Environ. Chem. Eng., vol. 4, no. 2, pp. 1769-1779, 2016.

[6] I. Ali, M. Asim, and T. A. Khan, "Low cost adsorbents for the removal of organic pollutants from wastewater," J. Environ. Manage., vol. 113, pp. 170183, 2012.

[7] H. Zaghouane-Boudiaf, M. Boutahala, S. Sahnoun, C. Tiar, and F. Gomri, "Adsorption 
characteristics, isotherm, kinetics, and diffusion of modified natural bentonite for removing the 2,4,5trichlorophenol," Appl. Clay Sci., vol. 90, pp. 81-87, 2014.

[8] T. L. C. Morandini and A. do L. Leite, "Characterization and hydraulic conductivity of tropical soils and bentonite mixtures for CCL purposes," Eng. Geol., vol. 196, pp. 251-267, 2015.

[9] M. Toor, B. Jin, S. Dai, and V. Vimonses, "Activating natural bentonite as a cost-effective adsorbent for removal of Congo-red in wastewater," $J$. Ind. Eng. Chem., vol. 21, pp. 653-661, 2015.

[10] T. S. Anirudhan and M. Ramachandran, "Adsorptive removal of basic dyes from aqueous solutions by surfactant modified bentonite clay (organoclay): Kinetic and competitive adsorption isotherm," Process Saf. Environ. Prot., vol. 95, pp. 215 225, 2015.

[11] M. Turabik, "Adsorption of basic dyes from single and binary component systems onto bentonite: Simultaneous analysis of Basic Red 46 and Basic Yellow 28 by first order derivative spectrophotometric analysis method," J. Hazard. Mater., vol. 158, no. 1, pp. 52-64, 2008.

[12] Y. F. Hao, L. G. Yan, H. Q. Yu, K. Yang, S. J. $\mathrm{Yu}$, R. R. Shan, and B. Du, "Comparative study on adsorption of basic and acid dyes by hydroxy-aluminum pillared bentonite," J. Mol. Liq., vol. 199, pp. 202-207, 2014.

[13] A. Tor and Y. Cengeloglu, "Removal of congo red from aqueous solution by adsorption onto acid activated red mud," 2006.

[14] S. J. SANTOSA, S. J. NARSITO, and A. LESBANI, "The Determination of Active Site, Capacity, Energy and Rate Constant on the Adsorption of Zn(II) and Cd(II) on Chitin," J. Ion Exch., vol. 14, no. Supplement, pp. 89-92, 2003.

[15] Q. H. Hu, S. Z. Qiao, F. Haghseresht, M. A. Wilson, and G. Q. Lu, "Adsorption study for removal of basic red dye using bentonite," Ind. Eng. Chem. Res., vol. 45, no. 2, pp. 733-738, 2006. 